\title{
QUEEN'S
UNIVERSITY
BELFAST
}

\section{Chinese export competition, declining exports and adjustments at the industry and regional level in Europe}

Flueckiger, M., \& Ludwig, M. (2015). Chinese export competition, declining exports and adjustments at the industry and regional level in Europe. Canadian Journal of Economics, 48(3), 1120-1151.

https://doi.org/10.1111/caje.12170

\section{Published in:}

Canadian Journal of Economics

\section{Document Version:}

Peer reviewed version

Queen's University Belfast - Research Portal:

Link to publication record in Queen's University Belfast Research Portal

\section{Publisher rights}

(C) 2016 Canadian Economics Association.

This work is made available online in accordance with the publisher's policies. Please refer to any applicable terms of use of the publisher.

\section{General rights}

Copyright for the publications made accessible via the Queen's University Belfast Research Portal is retained by the author(s) and / or other copyright owners and it is a condition of accessing these publications that users recognise and abide by the legal requirements associated with these rights.

Take down policy

The Research Portal is Queen's institutional repository that provides access to Queen's research output. Every effort has been made to ensure that content in the Research Portal does not infringe any person's rights, or applicable UK laws. If you discover content in the Research Portal that you believe breaches copyright or violates any law, please contact openaccess@qub.ac.uk. 


\title{
Chinese Export Competition, Declining Exports
}

\author{
and Adjustments at the \\ Industry and Regional Level in Europe* \\ Matthias Flückiger ${ }^{\dagger}$ \\ Markus Ludwig $\ddagger$ \\ University of Basel \\ University of Basel
}

June 4, 2014

\begin{abstract}
We analyze how a set of 22 European countries is affected by increased Chinese export competition between 1995 and 2008. Employing product group-level data, we observe a reduction in the export volumes of European countries due to increased Chinese export competition. This deceleration in the export sector induces changes within the manufacturing industries, especially a decline in employment. When using more aggregated, regional-level data, our analysis shows that the industry sector as a whole declines, resulting in an increased unemployment rate. The importance of Chinese export competition for Europe is attributable to its high export intensity.
\end{abstract}

JEL Classification: F14, F16

KEywords: China, Export Competition, Industry Labor Decline

\footnotetext{
${ }^{*}$ We would like to thank Frank Krysiak, Jürg H. Sommer, Christian Rutzer, Hermione Miller-Moser, two anonymous referees and the participants of the 2013 CEA conference in Montréal as well as the participants of the economics lunch at the Faculty of Business and Economics of the University of Basel for valuable suggestions and comments. This paper constitutes a comprehensively revised version of the WWZ working paper circulated under the title 'Made in China: Export Competition and Structural Changes in the OECD Countries'.

${ }^{\dagger}$ Contact Address: University of Basel, Faculty of Business and Economics, Peter-Merian-Weg 6, Postfach, 4002 Basel, Switzerland. Email: matthias.flueckiger@unibas.ch

${ }^{\ddagger}$ Contact Address: University of Basel, Faculty of Business and Economics, Peter-Merian-Weg 6, Postfach, 4002 Basel, Switzerland. Email: markus.ludwig@unibas.ch
} 


\section{Introduction}

The emergence of China as a major player in the world market for manufactured goods is well documented. Driven by institutional changes, the successive adoption of new technologies and the existence of a vast pool of labor, China's exports have increased rapidly. As a consequence, China's market share has sharply risen. In 1995, for example, the volume of China's manufacturing exports relative to the exports of the European countries amounted to 8 percent. By 2010, this ratio had grown to 29 percent. $^{1}$

This supply shock has resulted in a considerable increase in competition in the global market for manufactured products. This is particularly true for European countries, due to the fact that their export portfolios are very similar to the Chinese export bundle. ${ }^{2}$ This strong overlap indicates that the competition for the European export sector is highly intensive. In addition, the export intensity of the European manufacturing industries is very high. On average 51 percent $^{3}$ of their goods are exported, which implies that the export market is more important than the domestic market for European countries. ${ }^{4}$ So far, little attention has been paid to investigating the impact that increased export competition from China has on European economies; i.e., the effects of an increased share of Chinese products in Europe's export markets. This paper makes a first contribution to filling this gap. We analyze whether intensified Chinese export competition is associated with the decline of the European countries' export sectors and additionally investigate whether such changes induce adjustments within and between manufacturing industries.

Starting with a cursory review of the data, there is no indication that a negative relationship exists between the emergence of China in the world market for manufactured goods and the export volumes of European countries. Manufacturing exports have even grown relative to GDP over time (Bergoeing et al. 2004). However, when the degree of Chinese export competition is taken into account, diverging patterns emerge. To measure the degree of Chinese export competition, we compute the home country's trade partners' share of total imports originating in China. This measure is invariant to market size and market-specific demand shocks. In Figure 1, we divide the exports of manufactured products into two groups,

according to whether Chinese export competition for these products lies above or below the 
overall mean. As can be seen, the value of exports relative to GDP for the product groups facing strong competition increased marginally between 1995 and 2000 and has subsequently decreased, despite a continuous decline in transport costs. On the other hand, the export volume of manufactured products facing only weak competition grew considerably relative to GDP. Additionally, Figure 2 shows that the share of manufactured products for which European countries face intense Chinese competition ${ }^{5}$ has steadily increased over time. The two graphs suggest that strong Chinese competition in the world market leads to a decline in the volume of European manufacturing exports and that the range of products for which the countries face intense competition has increased over the last decade.

Figure 1: European Exports in Markets with Weak and Strong Chinese Export Competition

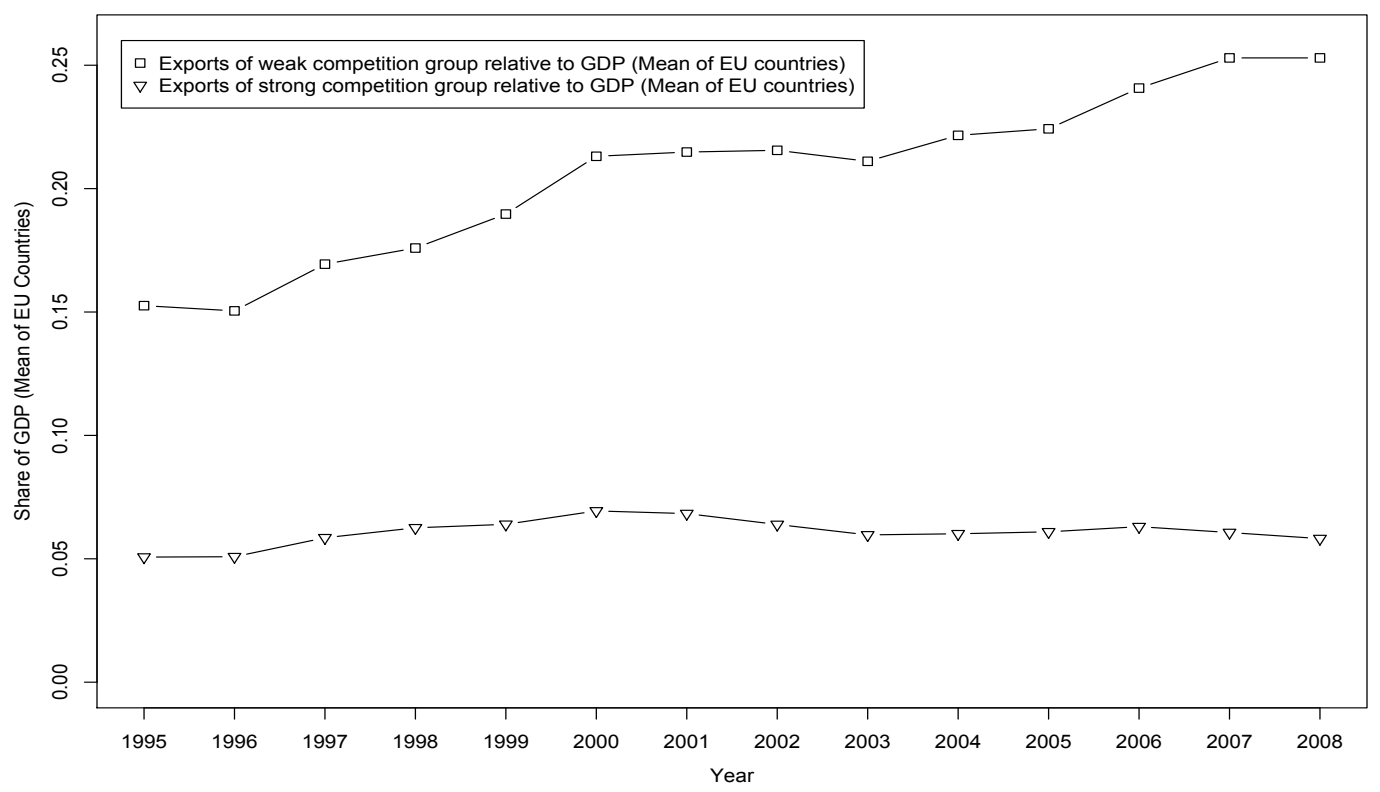

Note: The strong (weak) competition group is categorized as follows: Product classes for which export competition, as defined by Eq. (1), is above (below) average.

Considering the well-established facts that exporting firms differ from non-exporters ${ }^{6}$ and that changes in the export sector influence the intra-industry structure (e.g., Melitz (2003) or Bernard et al. (2003)), the reduction in exports associated with increased Chinese export competition is likely to affect the industry's structure in the home economies.

In our empirical analysis, we employ panel data at different levels of aggregation for a sample of 22 European countries. The data spans the period 1995-2008. To break the mechanical link between the export volume of the home country and our export competition measure, 
Figure 2: Proportion of Product Classes Facing Intense Chinese Export Competition

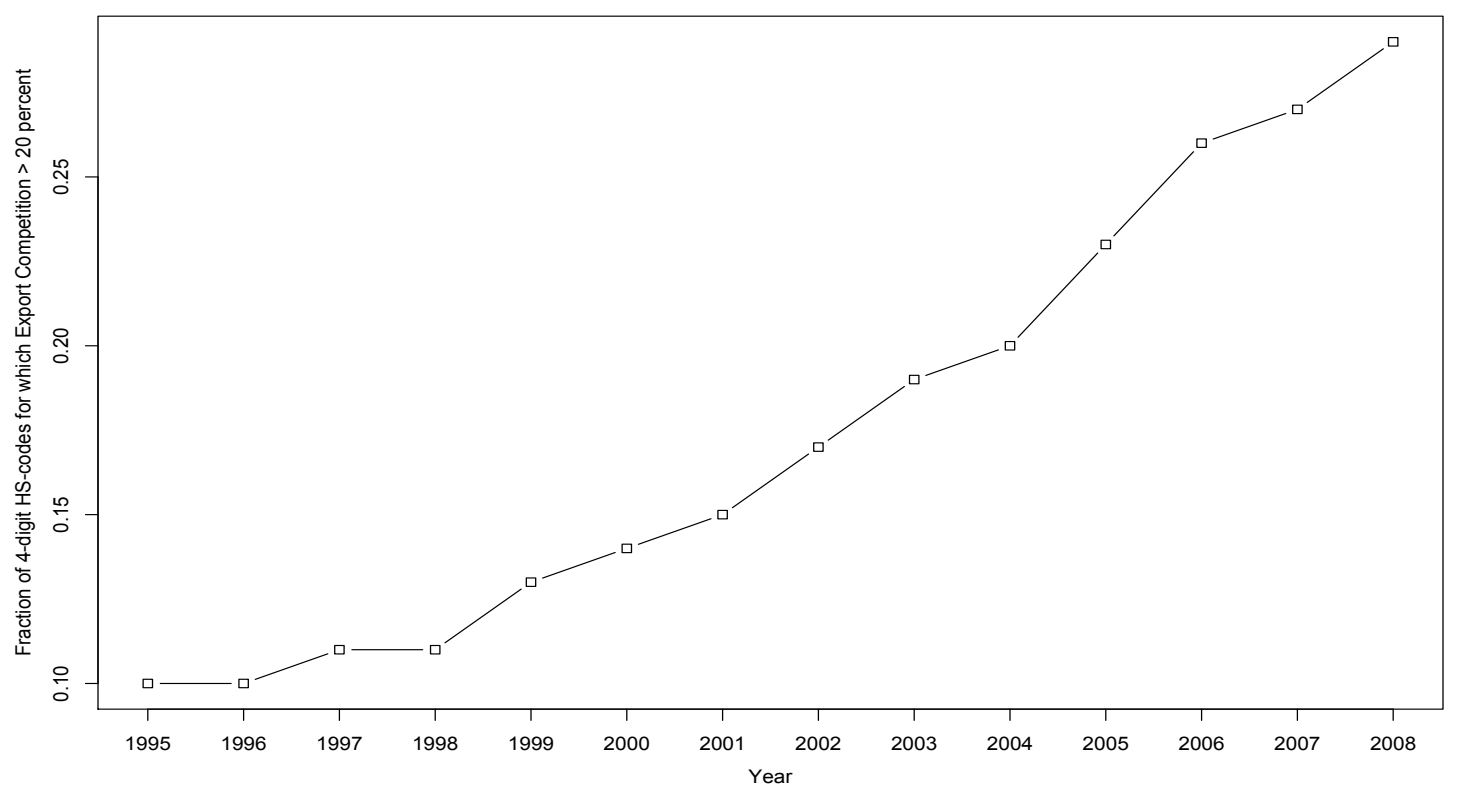

Note: Export competition is defined according to Eq. 11.

which might cause an endogeneity bias, we employ an instrumental variable strategy. To establish the robustness of our results, we use several alternative instruments.

In a first step, we use bilateral trade data to establish that Chinese export competition has a significant and negative effect on the export volume of the European countries. We find that an increase of one percentage point in Chinese export competition leads to a decline in the home country's export volume of between -0.3 and -0.55 percent. We subsequently investigate whether this distortion in the export market is associated with a decrease in the total output of the manufacturing industries. The resulting estimates imply that moving from the lowest to the highest quintile in Chinese export competition is associated with an output reduction of -25 percent. This signifies a considerable reduction in industrial production and reflects the importance of the export sector in the European economies. The effect is powerful enough to induce changes at the industry level. In particular, the industryspecific output decline is associated with a strong employment adjustment. Its magnitude is equal to the decrease in output. This result suggests that Chinese export competition has contributed to the overall decline in industrial employment in Europe during the last decades. 
Additionally, we observe a reduction in the average firm size. Our results therefore accord with the findings of previous studies that document the crucial role that changes in exporting firms' market environment play in explaining changes within industries. Unsurprisingly, the data also shows that industries which are more export-oriented are affected more severely by an increase in Chinese export competition.

In a third step, we construct a measure of Chinese export competition for regions within the individual European countries. We then investigate whether Chinese export competition-a measure that solely captures variation in the export markets for manufactured goodsis observable at the regional level. We find, among other things, that the total number of workers employed in the manufacturing sector declines as Chinese export competition increases. We observe an increase in the unemployment rate, an increment in geographical mobility as well as inter-sectoral mobility towards the service sector as a result of this labor adjustment.

Overall, our analysis indicates that increased Chinese competition in the export markets induces a contraction in the European countries' manufacturing sectors. The resulting adjustment processes predominantly work through the employment channel. By progressively moving through different layers of data aggregation, we hope to unfold a consistent picture of how the increase in Chinese competition in the export markets for manufactured goods affects European economies.

The structure of the subsequent analysis is the following: In Section 2 we review the literature related to our analysis and in Sections 3 , we deliver some preliminary remarks. Sections 4 to 6 consecutively analyze the impact of Chinese export competition on European manufacturing at the three different levels of aggregation, where each section uses the following structure: First, we introduce the measure for the degree of Chinese export competition. Next, we present the empirical strategy and discuss potential problems regarding the identification of the export competition effect. In the third step, we present the data before discussing the results of the empirical analysis in the fourth step. Finally, Section 7 concludes. 


\section{Related Literature}

The literature dealing with the emergence of China as a major player in the world market for manufactured goods is vast. However, studies specifically concerned with assessing the effects that operate through the export market channel have mostly been restricted to the quantification of the crowding-out effect observed for developing countries specializing in the production of labor-intensive goods. Generally, the effects are found to be rather small. Hanson and Robertson (2010) estimate that the percentage of foregone exports for these countries over the period 2000-2005 due to increased Chinese competition lies between 0.5 and 1.6 percent. For the consumer goods exports of Asian countries, evidence for a crowdingout effect is found by Eichengreen et al. (2007). A crowding-out effect for Asian countries is also documented by Xing (2011) in the market for information communication technology products. Regarding the substitution in the U.S. market from Latin American imports towards Chinese products, Moreira (2007), López-Córdova et al. (2008) and Montenegro et al. (2011) find small or non-significant effects. However, using an alternative measure for competitive threat, the results of Jenkins (2020) indicate that the negative impact on Latin American exports could be considerably stronger than that found in the studies mentioned above. A possible explanation for the relatively small effects documented in the above analyses is provided by Husted and Nishioka (2013). They show that developed countriesrather than developing countries - are negatively affected by the increase in China's world market share.

For European countries, the analysis of possible effects relating to increased export competition from Chinese products has received little attention, although Schott (2008) documents an increasing overlap between the export bundles of OECD countries and China. In addition, Cadot et al. (2013) document an increase in the concentration of imports of OECD countries with respect to their geographical origin beginning approximately in the year 2000 . This concentration process is entirely attributable to China's growing import share in OECD countries. To the authors' knowledge, the issue of whether home industries or labor markets are affected by increased Chinese competition in the export market has only been addressed in Autor et al. (2013). They incorporate the growth in Chinese imports in third markets 
into a measure for local labor market exposure to Chinese products. However, the isolation of the effect that operates through the export sector is not possible within the framework of their paper.

The analysis of potential effects associated with increased Chinese competition in home markets - i.e., import competition - has attracted more interest. Regarding the impacts on the labor markets, studies consistently find a negative correlation between manufacturing employment and exposure to imports from China. Using information on local U.S. labor markets, Autor et al. (2013) find that increased exposure to Chinese imports is negatively associated with the share of workers employed in the manufacturing sector. Similarly, Pierce and Schott (2012) find that the U.S. manufacturing employment declined considerably as a result of granting permanent normal trade relations to China in 2000.

In line with the results of Bernard et al. (2006), indicating that industrial plant growth and survival are negatively associated with exposure to imports from low-wage countries, Bloom et al. (2011), Mion and Zhu (2013) as well as Álvarez and Claro (2009) find evidence that exposure to Chinese imports is associated with lower plant-level employment growth. Álvarez and Claro (2009) as well as Sargent and Matthews (2009) additionally find a positive correlation between Chinese import penetration and the market exit probability of firms in the manufacturing sector for developing countries. On the basis of industry-level data for 10 European countries operating in selected manufacturing sectors, Peltonen et al. (2008) establish a negative association between the import penetration of Chinese products and company profitability. More recently, Auer et al. (2013) show that European producers experience a considerable downward pressure in prices when imports from China increase. Regarding the impact on manufacturing wages, the results are mixed. Álvarez and Opazo (2011), in line with the predictions of the Heckscher-Ohlin model, attribute a negative wage effect in the manufacturing sector to the import penetration of Chinese products. On the other hand, several studies document skill and technology upgrading as a reaction to increased import competition (see e.g., Mion and Zhu (2013), Bloom et al. (2011) or Álvarez and Opazo (2011)), implying a positive effect on productivity and wages. In line with these results, Isgut (2006) finds a positive wage effect for Canada's manufacturing workers. Autor 
et al. (2013) do not find a significant effect on wages in the manufacturing sector. ${ }^{7}$

These inconclusive results regarding manufacturing wages also relate to the strand of literature documenting wage rate rigidities, implying employment adjustments instead. For example, Babecký et al. (2010) document the existence of downward wage rigidity in real and nominal terms for a set of European firms. Similarly, Druant et al. (2012) find that the manufacturing sector in European countries adjusts wage rates less frequently than prices. Also related to our study is the analysis of the continuing relative growth of the service sector in developed economies (see e.g., Autor and Dorn (2013)). The existing studies find that international trade - most prominently via offshoring - plays only a minor role in explaining the cross-sectoral labor movements.

Finally, our work is able to contribute to the ongoing discussion about the causes of the increasing inter-regional employment and population disparities in Europe (Farole et al. 2011; Puga, 2002). A possible explanation is provided by Broyer and Eschwege (2012). They document considerable deindustrialization among the European regions and an associated decline in manufacturing employment. According to Affuso et al. (2011), international trade contributes to this process by exposing industries to fiercer competition. Given the ample evidence that employment opportunities and the general economic outlook are driving forces of migration - especially among young people ${ }^{8}$ - this increased exposure to competition is likely to be linked to the existing differences in the population dynamics of the European regions. The results of Bucher and Mai (2005) reveal that one third of the European regions have experienced a decline in population. Increased outward migration is an important factor contributing to this decrease. So far, the existence of a link between the disparities mentioned above and the intensified Chinese competition has not been investigated.

All in all, the survey presented in this section has shown that the literature which analyzes the effects of increased Chinese competition operating through the export market channel and focusing on developed countries is scarce. Beginning with the next section, we will address some of the open questions that exist. 


\section{Preliminary Empirical Remarks}

We are interested in analyzing the effects on a home country that arise from changes in the degree of Chinese competition in its export markets. Because we lack adequate firmlevel data - e.g., information that would allow us to directly link production and export data - we have to rely on different levels of data aggregation in order to answer our research question. Specifically, we successively investigate (1) whether the export volume of European countries, measured at the product group level, is negatively affected by an increase in Chinese export market competition; (2) whether the changes in the export markets due to intensified competition from China are detectable at the industry level of the home countries; and (3) whether the changes in the export markets are strong enough to induce alterations within the regions of the European home countries. Because of the broad scope of our analysis, we focus primarily on the assessment of the average effects in our empirical analysis. Occasionally, we will differentiate our analysis with respect to different subgroups in order to identify where Chinese export competition has a particularly strong effect.

In order to enhance the readability, we will discuss the definition of the export competition measure, the empirical setup and the available data separately for each level of data aggregation. We start at the product level and subsequently move to successively more aggregated levels, whereby, each level builds on the preceding one.

\section{Chinese Competition and Export Volumes}

In this study, we argue that product-specific Chinese supply shocks result in an increase of Chinese goods in the export markets. This increases the competition in the export markets and, as a consequence, induces a decline in the exports of the home country. These changes in exports, owing to Chinese supply shocks, are our first variable of interest. Unfortunately, this variable is not directly observable. ${ }^{9}$ We therefore first have to establish (and quantify) that, in fact, Chinese export competition has an negative effect on the export volumes of the European countries. In this section, we therefore analyze whether the exports from the European countries to a specific export market decrease when Chinese competition in that 
market intensifies.

To measure the degree of Chinese competition in the export market, we need to define a measure that: (a) captures the intensity of the competition owing to Chinese supply shocks; (b) accounts for the size of the respective import market; and also (c) accounts for any market specific demand shocks. Point (b) takes into account that an increase in the same absolute value of Chinese supply matters more in a small export market than in a large export market. Point (c) reflects the fact that an increase in Chinese supply, originating from a demand shock in the export destination, does not represent a Chinese supply shock.

\subsection{Export Competition Measure}

In the subsequent analysis, we will use the partner country's imports from China relative to its total imports within a given product category and year as our Chinese export competition measure. That is, we scale Chinese imports by the respective import market size. Formally, the export competition (EC) measure can be expressed as:

$$
E C_{i, j, k, t}=\frac{\operatorname{Im}_{j, k, t}^{C}}{\operatorname{Im}_{j, k, t}^{T}} \quad \text { with } \begin{array}{r}
\text { partner country: } j=1, . ., J \\
\text { home country: } i=1, . ., I \\
\text { product: } k=1, . ., K \\
\text { time: } t=1, . ., T
\end{array}
$$

where $E C_{i, j, k, t}$ is the degree of export competition for the home country $i$ in the partner country $j$ and product class $k$ in the year $t ; \operatorname{Im}_{j, k, t}^{C}$ are the imports of partner country $j$ from China in the product category $k$ at time $t$; and $\operatorname{Im}_{j, k, t}^{T}$ are the total imports from partner $j$ in product category $k$ at time $t$. The term 'total' refers to the sum of all the imports of a given partner country.

The measure in Eq.(1) is akin to the index introduced by Bernard et al. (2006). However, it is based on the imports of the partner countries and not on the imports of the home country. It represents China's market share with respect to all imports in a given product market and partner country and therefore captures the market penetration of Chinese products, independent of the size of the respective market. It is also invariant to demand shocks in 
the partner country that are common to all exporters.

By using this index, we argue that in markets with a high share of imports originating in China, the competition is fierce, whereas in markets with a low share of Chinese products, the competition is moderate. We expect that the export volume to markets with a high degree of EC decreases relative to the exports that are destined to markets with low Chinese competition. This reasoning is based on the observation that the price of Chinese products is relatively low compared to products originating from European countries (e.g., Schott (2008)). This implies, amongst other things, that profit margins for firms decrease, which

may, in turn, initiate an adjustment process. Substantiating this argumentation, Auer et al. (2013) show, that producer prices in Europe experience a considerable downward pressure when China's market share in the European countries increases.

\subsection{Empirical Strategy}

To analyze the association between the export volume and the degree of Chinese competition in the export destination, we use the following fixed effects approach:

$$
\ln \left(E X_{i, j, k, t}\right)=\beta_{0}+\beta_{1} E C_{j, k, t}+\mu_{i, j, k}+\theta_{i, t}+\gamma_{t}+\boldsymbol{\beta}_{2}{ }^{\prime} \mathbf{X}_{i, j, k, t}+\epsilon_{i, j, k, t}
$$

The dependent variable is the logarithm of the export volume $E X_{i, j, k, t}$ of the home country $i$ to the trade partner (export market) $j$ in product class $k$ in year $t$. The regression includes home country-partner country product-specific fixed effects $\mu_{i, j, k}$. Therefore, we will only exploit variation within a given trade partnership in a given product class. That is, we will solely rely on variation over time. To take into account any country time-variant effects, such as trends in demand or technological developments, we augment the regression by including home country-specific time trends $\left(\gamma_{t}\right)$. Furthermore, we add time fixed effects $\left(\theta_{i, t}\right)$ and a set of control variables $\left(\mathbf{X}_{i, j, k, t}\right)$, which we will discuss subsequently. The idiosyncratic error term is given by $\epsilon_{i, j, k, t}$. 


\subsubsection{Threats to Identification}

There are four main effects that could potentially bias the estimates of the EC coefficients. They are discussed successively.

(A) A mechanical link exists between the LHS variable in the regression setup (2) and the EC measure. The partner countries' total imports, constituting the denominator of the EC measure, also comprise the exports of the home country. Therefore, the denominator of the EC index in Eq.11) can be rewritten as:

$$
\operatorname{Im}_{j, k, t}^{T}=\sum_{c \neq i} \operatorname{Imp}_{c, j, k, t}+\operatorname{Imp}_{i, j, k, t}=\sum_{c \neq i} \operatorname{Imp}_{c, j, k, t}+\mathrm{EX}_{i, j, k, t} .
$$

Clearly, the last term in (3) and the LHS in (2) are linked by construction. A change in the exports of a home country automatically induces a change in the EC measure. Therefore, variations in the EC measure could simply capture alterations in the home market, independent of the Chinese exports. To break the mechanical link, we construct an instrumental variable by computing the denominator as the sum of partner country $j$ 's total imports, excepting its imports originating in the home country $i$. Formally, the instrument is given by:

$$
\operatorname{PIV}_{i, j, k, t}=\frac{\operatorname{Im}_{j, k, t}^{C}}{\sum_{c \neq i} \operatorname{Im}_{c, j, k, t}}
$$

Ex-ante, the variation in the instrument is consequently only dependent on alterations in the export market. In the subsequent analysis, we will refer to this instrument as our "primary instrument' (PIV).

(B) A second concern is that our EC measure is correlated with the product-specific imports to the home country, i.e., the Chinese import competition. The existence of such a correlation would make the isolation of the effect that works through the export market channel very difficult. In Sections 4, 5 and 6, we show that the EC measure (PIV) is uncorrelated with the Chinese imports in the home markets, allowing for the isolation of the export competition effect. Unfortunately, we are unable to derive any insight regarding the 
importance of the export competition effect relative to the import competition effect, as we do not have a suitable instrument for the latter effect.

(C) A third potential problem is that the correlation between the LHS variable and the EC measure could arise due to common shocks affecting the European countries. These shocks would affect our relative measure for export competition by influencing the denominator. Assume, for example that we want to analyze the association between Germany's exports to Australia and the degree of Chinese competition in the Australian market. If the European countries experience a negative supply shock, ceteris paribus, Germany's exports to Australia will fall. At the same time, the EC measure (and the PIV) in the Australian market will increase simply because the denominator of Eq.(1) decreases as a result of the common shock in Europe. The resulting negative relationship between the export volume and the EC measure would therefore reflect the common shock in Europe and not - as is our goalcapture changes due to increased Chinese competition.

To demonstrate that common European shocks do not drive our results, we conduct a robustness check by holding the non-Chinese part of the denominator in Eq. (4) constant over time. This modified instrument only captures variation in the export market stemming from changes in Chinese imports and is therefore independent of European supply shocks. The robustness check, presented in detail in Technical Appendix ? ${ }^{10}$, delivers quantitatively and qualitatively similar results compared to the use of the PIV. We therefore conclude that common supply shocks for European countries do not bias our results and consequently report the estimations results obtained using the PIV. An observation that further supports the assumption that Chinese supply shocks, rather than shocks in the European countries, cause changes in the EC measure is that Chinese productivity growth has been high over the last decades. Between 1995 and 2008, for example, China's TFP growth outpaced Europe by 2.4 percent annually (The Conference Board, 2013). Similarly, China's export growth in the manufacturing sector was 3.4 times higher compared to that of the EU countries. ${ }^{11}$ Multiple studies indicate that this increase is mainly due to factors particular to China, such as labor market reforms and privatization of previously state-owned firms (see e.g., Knight and Ding (2012)). China's increase in the market share in the world market for manufactured goods 
and the resulting increase in the EC measure is therefore the result of a Chinese supply shock. ${ }^{12}$

To additionally mitigate any supply shock-related issues, we include time-specific dummies in all regression setups and control for the absolute export volumes of a given home country within a given year. These variables will at least partially capture potential supply shocks. (D) The internal forces driving China's export growth mentioned above also reduce the degree to which our estimates might be biased due to demand shocks. The results of Autor et al. (2013) reinforce this view. A demand shock (biased towards Chinese goods) in the partner country would lead to an increase in the EC measure. In this case, our estimates would be downward biased. We cannot completely rule out a contamination of our estimates arising from possible demand shocks. However, we try to minimize such an impact by including the value of the partner country's total imports. An increase in demand should be absorbed by the co-movement of the total import volume.

To show that demand shocks are unlikely to pose a problem for our estimates, we define an alternative instrument in an additional robustness check. An instrument is constructed as China's global market share within a product class and year. This value is not export market-specific and therefore captures the overall (relative) extent of China's gain in world supply. To obtain export market-specific variation, we weight China's world market share using the geographical distance between China and the respective export market. The construction of this alternative instrument is presented in detail in Appendix ?? along with the resulting estimates. It is reassuring that these estimates are very similar to those of the setup using the PIV.

Finally, to further support the validity of our identification strategy, we introduce an instrument that does not rely on trade flow data. The instrument is given by the tariff rates applied to Chinese imports in the respective partner country. We expect that a decline in the tariff rates will promote the access of Chinese products to the market and thereby constitute an exogenous source of variation - with respect to the home exports - in the share of Chinese products in this market. As with the other robustness checks, the resulting EC coefficient using the tariff rates as the instrument is of similar size and sign, thus providing 
strong support and endorsing the plausibility of our regression results.

Before presenting the regression results, we describe the product-level data in the next step.

\subsection{Product-Level Data}

The product-level data is drawn from the UN Comtrade Database and is categorized according to the four-digit Harmonized Commodity Description and Coding System (HS). The database contains information regarding the value of bilateral trade flows, measured in current U.S. dollars, among almost 200 countries for a wide range of product groups. In this study, we restrict our attention to the analysis of products belonging to the class of manufactured goods. This implies the inclusion of the four-digit HS codes in the range between 2800 and 9699. For brevity's sake, we will refer to the four-digit product groups as 'products' throughout the paper.

Because the product groups do not distinguish between intermediate and final goods, we are not able to identify possible differential effects for different stages in the supply chains.

From the Comtrade database, the following trade flows are extracted and used in the analysis: The export competition measure described in Eq.(1) is constructed by taking the imports of the home country's partner country originating from China within a given product classification and year and dividing these by the total imports of the trade partner. To control for the absolute trade volumes, we supplement the dataset with the total imports of the home and partner country as well as the exports of the home country. These absolute volumes are also reported at the product level and are measured in current U.S. dollars. Note that trade volumes which are inexistent, either due to missing values or the absence of trade, are not documented in the Comtrade Database. Our dataset therefore does not include zeros; neither for the dependent or the explanatory variables. To the set of control variables, we add country-specific information on the GDP per capita of the home and partner country. This information is drawn from the Development Indicators and is measured in constant international U.S. dollars (PPP). Lastly, as an alternative instrumental variable, we augment the dataset by adding the weighted mean ad valorem tariff rates applied to the Chinese products by the respective partner country. This information is available from the 
UNCTAD Trade Analysis and Information System (TRAINS).

We will restrict our analysis to observations, where the home countries are situated in Europe. More specifically, we only include observations for European countries that are members of the OECD. We will subsequently refer to this group of 22 countries as 'EG' countries.

It is important to note that this restriction only applies to the home countries, i.e. the set of dependent variables. The set of possible partner countries remains unconstrained: that is, the exports from the set of European countries listed above to all their trade partnersincluding the non-EG countries - will be incorporated in the analysis. The final dataset contains 5,604,162 observations spanning the period 1995-2008.

\subsection{SLS Results}

Table 1 depicts the results of the product-level regressions. The robust standard errors - in parenthesis - are reported at the home country-partner country-product level. Columns 1 and 2 present the reduced form estimates of our primary instrument, PIV, on the home country imports from China and on the exports, respectively. The first column documents that the PIV coefficient is non-significant (with a p-value close to one) and close to zero when the log value of Chinese imports are used as the dependent variable. On the other hand, a strong negative correlation exists between the export volume and the PIV. These findings demonstrate that the EC measure affects the export volume, but that it is unrelated to the home country's imports from Chinese. This ensures that our instrument does not pick up any effects stemming from increased Chinese import competition. This, in turn, allows for the identification of the export competition effect.

Columns 3-6, depict the 2SLS estimates. Column 3 shows the results of regression model (2) when the EC measure is instrumented with the PIV and time-trends, country-partnerproduct-specific fixed and time fixed effects are included. The p-value of the F-statistic for the excluded instrument indicates that the model is well identified. This applies to all the regression setups presented in Table $1,{ }^{13}$ The EC coefficient is significant and exhibits the expected negative sign. The results of the first-stage regression depict a strong and positive 
Table 1: Chinese Competition and Export Volumes

\begin{tabular}{|c|c|c|c|c|c|c|}
\hline \multirow[t]{2}{*}{ Dependent variable: } & \multirow{2}{*}{$\begin{array}{l}\text { Log Imports } \\
\text { from China }\end{array}$} & \multicolumn{5}{|c|}{ Log exports } \\
\hline & & $(2)$ & $(3)$ & $(4)$ & $(5)^{a}$ & (6) \\
\hline PIV & $\begin{array}{c}0.002 \\
(0.011)\end{array}$ & $\begin{array}{c}-0.272^{* *} \\
(0.012)\end{array}$ & & & & \\
\hline $\begin{array}{l}\text { Export } \\
\text { competition }\end{array}$ & & & $\begin{array}{c}-0.284^{* *} \\
(0.011)\end{array}$ & $\begin{array}{c}-0.305^{* *} \\
(0.011)\end{array}$ & $\begin{array}{c}-0.554^{* *} \\
(0.215)\end{array}$ & $\begin{array}{c}-0.305^{* *} \\
(0.011)\end{array}$ \\
\hline $\begin{array}{l}\text { Log total imports } \\
\text { of home country }\end{array}$ & & & & $\begin{array}{c}0.064^{* *} \\
(0.003)\end{array}$ & $\begin{array}{c}0.065^{* *} \\
(0.004)\end{array}$ & $\begin{array}{l}0.064^{* *} \\
(0.003)\end{array}$ \\
\hline $\begin{array}{l}\text { Log total imports } \\
\text { of partner country }\end{array}$ & & & & $\begin{array}{l}0.339^{* *} \\
(0.002)\end{array}$ & $\begin{array}{c}0.342^{* *} \\
(0.003)\end{array}$ & $\begin{array}{l}0.339 * * \\
(0.002)\end{array}$ \\
\hline $\begin{array}{l}\text { Log total exports } \\
\text { of home country }\end{array}$ & & & & $\begin{array}{c}0.536^{* *} \\
(0.003)\end{array}$ & $\begin{array}{c}0.534^{* *} \\
(0.004)\end{array}$ & $\begin{array}{l}0.536^{* *} \\
(0.003)\end{array}$ \\
\hline $\begin{array}{l}\text { Log GDP p. capita } \\
\text { of home country }\end{array}$ & & & & $\begin{array}{l}1.027^{* *} \\
(0.044)\end{array}$ & $\begin{array}{c}1.025^{* *} \\
(0.044)\end{array}$ & $\begin{array}{l}1.027^{* *} \\
(0.044)\end{array}$ \\
\hline $\begin{array}{l}\text { Log GDP p. capita } \\
\text { of partner country }\end{array}$ & & & & $\begin{array}{l}1.096^{* *} \\
(0.014)\end{array}$ & $\begin{array}{c}1.098^{* *} \\
(0.014)\end{array}$ & $\begin{array}{l}1.096^{* *} \\
(0.014)\end{array}$ \\
\hline First stage: & & & & Export co & mpetition & \\
\hline PIV & & & $\begin{array}{c}0.955^{* *} \\
(0.000)\end{array}$ & $\begin{array}{c}0.955^{* *} \\
(0.000)\end{array}$ & & $\begin{array}{l}0.955^{* *} \\
(0.000)\end{array}$ \\
\hline $\begin{array}{l}\text { Tarifs CHN } \\
\quad(\text { partner })(\times 1000)\end{array}$ & & & & & $\begin{array}{c}-0.754^{* *} \\
(0.0164)\end{array}$ & $\begin{array}{r}-0.021^{* *} \\
(0.0164)\end{array}$ \\
\hline Obs. & 5604162 & 5604162 & 5604162 & 5604162 & 5604162 & 5604162 \\
\hline RMSE & 1.180 & 0.984 & 1.179 & 1.144 & 1.144 & 1.144 \\
\hline F-test exclud. IV & & & 0.000 & 0.000 & 0.000 & 0.000 \\
\hline
\end{tabular}

Note: $* p<0.05,{ }^{* *} p<0.01$. FE estimator regressions in all columns with home-partner-product specific effects, country specific time trends, time dummies and robust standard errors clustered at the home-partner-product level in parentheses. RMSE is the root mean square error. PIV is our standard instrument as described in the main text. Tarifs CHN (partner) is the duty rate applied to Chinese imports in the partner country. Log GDP per capita is in constant international U.S. dollars. The log import variables, both for the home country and the partner country, are on product level.

${ }^{a}$ In column 5 , the p-value of the Hansen test statistic is 0.25 (exclusion restrictions does hold).

correlation between the PIV and the export competition measure.

In column 4, we augment the model by adding the control variables for GDP and absolute trade volumes. The EC coefficient of -0.3 implies that a one percentage point increase in Chinese competition in the export market results in a -0.3 percent $^{14}$ decrease in the export volume of the home country. The results document that the competitive pressure induced by the Chinese products adversely affects the EG exporters. As the share of imports from China has steadily increased across most trading partners, this finding suggests a considerable cumulative loss in export volume for the EG countries. The effect is further amplified by the fact that Chinese exports grow not only within but also across product 
classes. The fact that the size of the EC coefficients in columns 3 and 4 (where additional control variables are added) are statistically indiscernible is reassuring, as this indicates that misspecifications arising through the addition of control variables are not an issue. Since adding potential confounders to the regression models does not change the EC coefficient size, we are confident that omitted variables do not constitute a problem for our estimates. Column 5 depicts the results when the tariff rate applied to Chinese products in the partner country is used as an alternative instrument. The results of the first-stage regression show that the correlation between the EC measure and the duty rate is significant and - as expected-negative. The coefficient size of the EC is now-with a value of 0.55 - somewhat larger, but still statistically indiscernible compared to the results in columns 3 and 4 . This is confirmed by the results presented in column 6 , where we employ both instruments in the regression. The introduction of a second instrument allows us to test the overidentifying restriction. The resulting p-value $(0.25)$ of the Hansen test statistic indicates that the instruments are valid, which-given the large number of observations - lends considerable credibility to our results; specifically, that we are able to identify the EC effects through the use of our instruments.

\section{Differentiation by Export Destination and Type of Goods}

Even though our analysis focuses on the assessment of average effects, it is insightful to analyze how the degree of Chinese export competition - and its effect - varies by export destination and product type. In Table 2 we show the regression results of Eq.(2) for different subsets of our sample. In column 1, we only include observations where the partner country is a member of the EU-15 states. The coefficient of -0.1 is small compared to the estimate of -0.32 presented in column 2. In the latter case, we restrict our sample to the export market destinations that are not part of the EU-15 group. This result shows that the effect of Chinese competition for the EG countries is much more pronounced in non-EU-15 export markets. A possible explanation for this finding is that the cost of trading with the EU-15 countries, e.g., in the form of tariffs or geographical distance to be covered, is extremely low for the EG countries. This in turn makes the products of the EG countries more competitive. 
Table 2: Chinese Competition and Export Volumes by Subset of Destination and Product Type

\begin{tabular}{|c|c|c|c|c|c|c|}
\hline \multirow[t]{3}{*}{ Dependent variable: } & \multicolumn{6}{|c|}{ Log exports } \\
\hline & EU-15 & Non-EU-15 & $\begin{array}{c}\text { Non-EU } \\
\text { High Income OECD }\end{array}$ & $\begin{array}{l}\text { Emerging } \\
\text { Economies }\end{array}$ & $\begin{array}{l}\text { Low-skill } \\
\text { product group }\end{array}$ & $\begin{array}{l}\text { High-skill } \\
\text { product group }\end{array}$ \\
\hline & $(1)^{a}$ & $(2)^{b}$ & $(3)^{c}$ & $(4)^{d}$ & $(5)^{e}$ & $(6)^{f}$ \\
\hline Export competition & $\begin{array}{c}-0.099^{* *} \\
(0.026)\end{array}$ & $\begin{array}{c}-0.324^{* *} \\
(0.012)\end{array}$ & $\begin{array}{c}-0.430^{* *} \\
(0.034)\end{array}$ & $\begin{array}{c}-0.338^{* *} \\
(0.020)\end{array}$ & $\begin{array}{c}-0.328^{* *} \\
(0.014)\end{array}$ & $\begin{array}{c}-0.214^{* *} \\
(0.019)\end{array}$ \\
\hline Avg. Export Competition & 0.079 & 0.121 & 0.180 & 0.112 & 0.147 & 0.074 \\
\hline Obs. & 1566376 & 4037786 & 571985 & 1339231 & 2539854 & 2693581 \\
\hline RMSE & 1.024 & 1.188 & 1.165 & 1.215 & 1.129 & 1.160 \\
\hline F-test excl. IV & 0.000 & 0.000 & 0.000 & 0.000 & 0.000 & 0.000 \\
\hline
\end{tabular}

Note: ${ }^{*} p<0.05,{ }^{* *} p<0.01$. 2SLS regression with excluded instrument in the first stage: The PIV and the endogenous variable export competition (not shown). FE estimator regressions in all columns with with home-partner-product specific effects, country specific time trends, time dummies and robust standard errors clustered at the home-partnerproduct level in parentheses. Analogously to Table1, all regressions include the log total imports of the home (partner) country, measured in current U.S. dollars, as well as the log GDP per capita of the home (partner) country, measured in constant international U.S. dollars, as control variables. The RMSE is the root mean square error. F-test excl. IV is the p-value of the instruments excluded in the first stage.

${ }^{a}$ In column 1, the sample is restricted to the subset of partners that are part of the EU-15 group.

${ }^{b}$ In column 2, the sample is restricted to the subset of partners that are not part of the EU-15 group.

${ }^{c}$ In column 3, the sample is restricted to the subset of partners that belong to the group of high income OECD countries, but which are not part of the EU15 group (World Bank classification).

${ }^{d}$ In column 4 , the sample is restricted to the subset of partners that are classified as emerging economies by the IMF ${ }^{e}$ In column 5, the sample is restricted to the subset of product groups that are classified as low skill goods (Basu) Forthcoming).

fin column b, the sample is restricted to the subset of product groups that are classified as high skill goods (Basu. Forthcoming).

This advantage is also implied by the relatively low degree of export competition in the EU-15 markets. As depicted in column 1, the average share of Chinese imports is only 8 percent in the EU-15 market. However, in the non-EU-15 markets, this share lies at 12 percent (column 2) and even increases to 18 percent (column 3) for the non-EU-15 highincome OECD country group. ${ }^{15}$ Consequently, the Chinese export competition in these latter countries has a pronounced negative effect for the EG economies. The EC coefficient in column 3 represents the effect of Chinese export market competition in the non-EU-15 high-income OECD countries. The coefficient in column 4 is obtained when restricting the sample to the export markets of the emerging economies. ${ }^{16}$ The size of the effects -0.43 and-0.33, respectively - are similar to estimates of the average effect presented in Table 1 . To conclude the analysis at the product level, we investigate the effect of Chinese export competition differentiated with respect to the type of goods. To this end, we split the products into two groups: a low-skill and a high-skill group of products (Basu, Forthcoming).

As shown in columns 5 and 6 , the export market penetration of Chinese products is higher for low-skill product than for high-skill products. Similarly, the effect of an increased EC is 
also higher for the first group of products. However, the effect for the high-skill products $(-0.21)$ is still considerable, indicating that the export portfolio of the EG countries as a whole is affected by the increase in Chinese competition.

Overall, our results document that the effect of Chinese export competition is substantial. Increasing Chinese export competition by one percentage point on average results in a drop in exports of between -0.3 and -0.55 percent depending on the regression setup. According to the point estimate in column 4 (Table 1), raising EC from the lowest to the highest quintile induces a drop in exports of 6 percent. We are able to show that our measure for export competition is unrelated to Chinese imports and, as a consequence, is decoupled from Chinese import competition. In the subsequent section, we investigate whether this exportvolume effect is strong enough to influence the industry-level output and the composition of manufacturing industries within EG countries.

\section{Chinese Competition and Changes at the Industry Level}

So far, we have assessed the negative relationship between shocks in the export market due to increased Chinese competition and the export volume of the EG countries. This correlation arises, because exporting firms in the home countries are affected by the increasingly competitive environment. Based on the fact that the export intensity of the European manufacturing sector is above 50 percent, and combined with the evidence that exporting firms on average employ more people, are more productive, and pay higher wages than non-exporters (e.g., Bernard et al. (2007)), and therefore play a crucial role in shaping the industry structure (Melitz (2003)), we expect that the variation originating in the export market is reflected in changes within the industries in the home country. In this section, we investigate the presence of such industry-level effects. Confined by the availability of data, we have to conduct the analysis at the industry level. Therefore, we need to aggregate the product-level trade flow variables presented in Section 4.3 including the EC measure - to the industry level. The procedure is described next. 


\subsection{Data Aggregation and EC Measure}

To analyze the effect of increased Chinese export competition at the industry level, we need an industry-specific measure for the degree of competition. We build this measure using the information contained in the product-level dataset. The combined use of the industry-level and the product-level data entails two difficulties: Firstly, the product-level classification is more detailed than the industry categorization. This requires the aggregation of the trade data to the industry classification. For this purpose, we construct a correspondence table which assigns the product codes to the industry classes. This process is described in Appendix ??. Secondly, because the information is no longer home country-export marketspecific, we cannot differentiate among individual trade partners anymore. For example, it is not possible to apportion the industry output to the respective export destinations. Therefore, in addition to the aggregation over product groups we also have to aggregate the trade data over the trade partners within a given home country, industry and year. For absolute values, the aggregation is straightforward: For a given industry, home country and year, we compute the sum of the product-level trade values. For the industry-level EC measure, a relative term, we build a weighted average over the product codes and partner countries. In the weighting process, we take into account the importance of the product class within its industry classification as well as the importance of the trade partners for each home country. Specifically, we compute the industry-level measure of Chinese export competition as:

$$
W E C_{g}=\sum_{k=1}^{K} \mathbb{I}\{k \in g\} \frac{E X_{k}^{T}}{E X_{g}^{T}} \sum_{j=1}^{J} \frac{I m_{j, k}^{C}}{I m_{j, k}^{T}} \frac{E X_{j, k}}{\sum_{j=1}^{J} E X_{j, k}} \quad \begin{array}{r}
\text { partner country: } j=1, . ., J \\
\text { with product: } k=1, . ., K \\
\text { industry: } g=1, . ., G .
\end{array}
$$

For notational convenience, time and home country dimensions are omitted. $W E C_{g}$ is the weighted export competition (WEC) measure for a given industry in the home country. $\mathbb{I}\{k \in g\}$ is the function indicating whether the product $k$ belongs to the industry $g . E X_{k}^{T}$ is the sum of the home country's exports of product $k$ across all trade partners. ${ }^{17} E X_{g}^{T}$ is the total value of the home country's exports within the industry class $g .{ }^{18}$ The first ratio in Eq. (5) therefore represents the importance of the individual product classes with respect to the total industry exports. The partner country's share of total imports originating from China is given by the second ratio. This import share is weighted according to the relative 
importance of the trade partner for the home country. The weight is given by the percentage of total exports shipped to partner country $j$. By construction, $W E C_{g}$ is between 0 and 1 and can therefore be interpreted as the weighted average share of imports from China across all partners and products. ${ }^{19}$

\subsection{Empirical Strategy}

Analogous to the product-level regressions, we employ a fixed effects approach. Specifically, the regression model is given by:

$$
y_{i, g, t}=\beta_{0}+\beta_{1} W E C_{i, g, t-1}+\mu_{i, g}+\theta_{i, t}+\gamma_{t}+\boldsymbol{\beta}_{2}{ }^{\prime} \mathbf{X}_{i, g, t-1}+\epsilon_{i, g, t},
$$

$y_{i, g, t}$ is the respective industry-level indicator under investigation within industry $g$, country $i$ and year $t$. The fixed effects $\mu_{i, g}$ are now at the home country-industry level. The estimates, therefore, again solely rely on variation over time within a given home-country and industry. The weighted EC measure is represented by $W E C_{i, g, t}$. Analogously to the product-level setup, we include country-specific time trends $\left(\theta_{i, t}\right)$ and time fixed effects $\left(\gamma_{t}\right)$. $\mathbf{X}_{i, g, t}$ represents the set of control variables which include information on GDP levels and the absolute amounts of industry-specific trade volumes. Because we assume that changes in the composition of trade materialize with a time lag in alterations in an industry's structure, we use the first lag of the explanatory variables. ${ }^{20}$

\subsubsection{Threats to Identification}

The threats to the identification of the effect of increased Chinese export competition are similar to the ones described in Section 4.2.1. Again, the WEC measure in Eq.(5) can change as a result of alterations in the home country markets. To avert any spurious changes in the WEC, for example stemming from (endogenously determined) changes in the composition of export destinations of the home country, we again apply an instrumental variable approach. The construction of the instrument is analogous to the procedure depicted in Eq. (5). However, to avoid spurious correlation imposed by the variation in the weights, we hold the weights - i.e., the first and the last ratio of Eq.(5) - fixed at their respective means. 
Table 3: Industry-Level Reduced Form Effects

\begin{tabular}{lcc}
\hline $\begin{array}{c}\text { Dependent } \\
\text { Variable }\end{array}$ & $\begin{array}{c}\text { Log Exports } \\
(1)\end{array}$ & $\begin{array}{c}\text { Log Imports from China } \\
(2)\end{array}$ \\
\hline WPIV & $-2.473^{* *}$ & -0.149 \\
& $(0.401)$ & $(0.831)$ \\
Weighted Tariff & $0.066^{* *}$ & 0.020 \\
CHN (partner) $\times 1000$ & $(0.011)$ & $(0.015)$ \\
\hline Obs. & 3737 & 3737
\end{tabular}

Note: ${ }^{*} p<0.05,{ }^{* *} p<0.01$. FE estimator regressions in all columns with country-industry-specific effects; countryspecific time trends; time dummies; and robust standard errors clustered at the country-industry level in parentheses. All regressions include the GDP per capita in log of constant international U.S. dollars; the imports from China and world imports aggregated over products (all in log). WPIV is our weighted primary instrument as described in the main text aggregated over products and partner with a time-invariant weighting. The weighted tariff CHN (partner) is the duty rate applied to Chinese imports in the partner country as described in the main text aggregated over products and partner with a time-invariant weighting. L. indicates lag.

As before, we use the total imports of the trade partner minus the imports originating in the home country as the denominator (i.e., our PIV) in the second ratio instead of the total imports. ${ }^{21}$ We will subsequently refer to this industry-level instrument as the weighted PIV (WPIV). To test the validity of our estimates more formally, we again use the tariff rates applied to Chinese products in the export market as an alternative instrument.

In Table 3, we show that both instruments are uncorrelated with the home country imports from China. Therefore, our estimates of the WEC coefficient do not capture any import competition effects. In column 2 of Table 3, we additionally document that the instruments significantly contribute to the variation in industry-level export volume. For example, a one percentage point increase in WPIV is associated with a -2.5 percent decrease in export volume. These results indicate that we are able to isolate the effect of increased Chinese competition that works through the export market channel, i.e. through the reduction in exports. In Table ?? in the Appendix, we further show that our estimates are not biased due to any aggregate shocks in Europe. All in all, we are confident that our estimation procedure adequately captures the industry-level effects of increased Chinese export competition.

\subsection{Industry-Level Data}

The industry-level dataset is constructed by combining industry-level data extracted from the Eurostat Database with the Comtrade product-level data described previously. We will use industry output (millions of euros), employment (head count), number of firms (head 
count), productivity (thousand euros per head) and wage rate (thousand euros) as the dependent variables, respectively. These variables are categorized according to the two-digit statistical classification of economic activities in the European Community (NACE Rev. 1.1). ${ }^{22}$ The data are stratified into 20 different industries. Its availability is restricted to the EG countries.

To analyze the effect of increased Chinese export competition on the industry characteristics mentioned above, we connect the industry data with the aggregated product-level trade flow data. Apart from the WEC measure, we include the absolute value of industry-level imports and exports as well as the tariff rates applied to Chinese goods in the export market into the analysis. ${ }^{23}$

Again, we augment the datasets by adding the country-specific GDP levels. The final dataset spans the period from 1995 to 2008 and contains 3,737 observations. Descriptive statistics of the dataset resulting from the matching procedure are provided in Table ?? in the Appendix.

\subsection{SLS Results}

Given the considerable negative correlation between the export volume and increased Chinese export competition, combined with the high degree of export intensity in the manufacturing sector of the EG countries, we expect that this negative association will also be observable for the total industry output. Consequently, we surmise that industry-specific variables will also be affected. We test these hypotheses by employing measures for the industry-specific output volume, employment, and earnings, as well as productivity as the dependent variable in the regression model Eq. (6). Additionally, we will also present evidence that industries with a high degree of export intensity, that is the ratio of exports to production, are more severely affected by Chinese export competition.

It is important to stress that, owing the weighting procedure employed with aggregation, it is difficult to compare coefficient sizes of the export competition measures across aggregation levels. To facilitate such a comparison, we will at times report the effect when moving from the lowest to the highest quintile within the sample variation of the respective export competition measure. 
Table 4: Chinese Export Competition and the Industry Structure

\begin{tabular}{lcccccc}
\hline $\begin{array}{c}\text { Dependent } \\
\text { Variable: }\end{array}$ & $\begin{array}{c}\text { Log industry } \\
\text { output }\end{array}$ & $\begin{array}{c}\text { Log number } \\
\text { of employees }\end{array}$ & $\begin{array}{c}\text { Employment } \\
\text { share within } \\
\text { manufacturing } \\
(1)\end{array}$ & $\begin{array}{c}\text { Log employees } \\
\text { per firm }\end{array}$ & $\begin{array}{c}\text { Log average } \\
\text { productivity }\end{array}$ & $\begin{array}{c}\text { Log wage } \\
\text { rate }\end{array}$ \\
& $(2)$ & $(3)$ & $(4)$ & $(5)$ & $(6)$ \\
\hline L. weighted & $-2.738^{* *}$ & $-2.549^{* *}$ & $-4.213^{* *}$ & $-1.881^{* *}$ & 0.355 & 0.007 \\
export comp. & $(0.690)$ & $(0.500)$ & $(1.231)$ & $(0.341)$ & $(0.341)$ & $(0.158)$ \\
$\quad$ & & L. weighted export competition & & \\
\multicolumn{1}{c}{ First stage: } & $0.575^{* *}$ & $0.575^{* *}$ & $0.575^{* *}$ & $0.575^{* *}$ & $0.575^{* *}$ & $0.575^{* *}$ \\
L. WPIV & $(0.031)$ & $(0.031)$ & $(0.031)$ & $(0.031)$ & $(0.031)$ & $(0.031)$ \\
& $-3.972^{* *}$ & $-3.972^{* *}$ & $-3.972^{* *}$ & $-3.972^{* *}$ & $-3.972^{* *}$ & $-3.972^{* *}$ \\
L. weighted tariff & $(0.737)$ & $(0.737)$ & $(0.737)$ & $(0.737)$ & $(0.737)$ & $(0.737)$ \\
CHN (partner) $\times 1000$ & 3737 & 3737 & 3737 & 3737 & 3737 & 3737 \\
\hline Obs. & 0.199 & 0.153 & 0.497 & 0.191 & 0.144 & 0.075 \\
RMSE & 0.000 & 0.000 & 0.000 & 0.000 & 0.000 & 0.000 \\
F-test excl. IV & 0.982 & 0.207 & 0.764 & 0.319 & 0.476 & 0.587 \\
Hansen p-value &
\end{tabular}

Note: ${ }^{*} p<0.05,{ }^{* *} p<0.01$. FE estimator regressions in all columns with country-industry-specific effects; countryspecific time trends; time dummies; and robust standard errors clustered at the country-industry level in parentheses. All regressions include the GDP per capita in log of constant international U.S. dollars; the imports from China and world imports aggregated over products (all in log). RMSE is the root mean square error. F-test excl. IV is the p-value of the instruments excluded in the first stage. Hansen p-value is based on the test $H_{0}$ : The instruments are valid. WPIV is our weighted primary instrument as described in the main text aggregated over products and partner with a time-invariant weighting. The weighted tariff CHN (partner) is the duty rate applied to Chinese imports in the partner country as described in the main text aggregated over products and partner with a time-invariant weighting. L. indicates lag.

The 2SLS results of the instrumental variable regressions with the two instruments WPIV and the weighted tariff rates applied to Chinese products are depicted in Table 4 . As mentioned in Section 5.2, all regressions include country-industry-specific effects, time dummies and country-specific time trends, as well as the full set of control variables. We report robust standard errors clustered at the country-industry level in parentheses. The p-value for the F-statistic of the excluded instrument indicates that the regression models are well identified. The table also depicts the Hansen statistic for the Null hypothesis: The instruments are valid. The value of the test statistic indicates that the validity cannot be rejected. As demonstrated in Appendix ??, all results are robust to the exclusion of the control variables. The resulting WEC coefficients are statistically indiscernible. We conclude that the potential bias in our estimates due to regression misspecification is not an issue.

The estimates presented in Table 4, column 1, confirm our conjecture regarding the negative effect of fierce Chinese competition in the export market with respect to the output volume of the affected industries. Increasing the WEC by one percentage point induces a decline in the industry-specific output of -2.7 percent. A strong increase in China's competitiveness 
therefore implies a severe reduction in output. Moving from the lowest to the highest quintile in WEC is associated with a -25 percent output decline.

Column 2 in Table 4 shows that the decline in industry-specific output is accompanied by strong employment adjustments. Industries reduce employment by -2.5 percent when experiencing a one percentage point increase in WEC. This finding implies that a considerable part of the labor reallocation is not taking place within the individual industries, e.g., from more productive to less productive firms. The lack of such an intra-industry adjustment process is also reflected in the diminishing relative importance - measured by the share of total manufacturing labor employed in the respective industries - associated with an increased exposure to Chinese export competition. Column 3 shows that the industry-specific share of total manufacturing employment drops by -0.04 percentage points as a result of a one percentage point increase in WEC. This amounts to one percent of the average labor share. The substantial employment effect indicates that the overall increase in Chinese export competition contributes to the general decline of the industrial sector in Europe. ${ }^{24}$ Column 4 depicts the dimension along which the labor force contraction is observable. As a consequence of a one percentage point increase in WEC, the average firm size decreases by -1.9 percent.

So far, we have documented that a growth in Chinese export competition triggers quantitative adjustment processes. An increase in WEC induces a decline in industry-specific output, employment and the average size of firms. However, as reported in columns 5-6 of Table 4, the relationship between our export competition measure and the industry-specific average productivity, as well as its wage rate is clearly insignificant. Thus, we do not observe any (reversed) effects along the Melitz-model arguments when the trade volume contracts as a result of increased WEC. This finding could reflect the fact that wages are rigid in Europe (e.g., Babecký et al. (2010)). Additionally, the loss in specific export markets does not necessarily imply that low productivity firms enter the industry, since wages do not adjust and labor can shift into other industries/sectors. The presence of such adjustment channels will be investigated in Section 6 .

Before moving to the detailed regional-level analysis, we look at the evolution of employ- 
ment differentiated with respect to the industries' export intensity and degree of Chinese export competition. Additionally, we investigate whether we can observe an intra-industry reallocation effect of production. However, because we do not observe flows in our data, e.g., employment or capital movements, we cannot identify the precise nature and magnitude of such intra-industry adjustments.

Export Intensity and Chinese Export Competition: Differential Effects for Industries

We first document that for industries that are more export oriented, by exhibiting a higher export intensity, Chinese export competition has a stronger effect. For illustration, we split the sample into two groups: one consisting of industries that exhibit an export intensity that lies above the median and the other consisting of industries that lie below the median. Table ?? in the Appendix shows that, in fact, export-intensive industries are more affected by Chinese export competition than industries that cater relatively more to the home market. Furthermore, Figure 3 , panel (a) shows that the observed overall reduction in manufacturing employment primarily takes place within the industries that exhibit a high degree of export intensity and are simultaneously confronted with strong Chinese export competition. This group of industries experiences a drop in employment of -32 percent between 1996 and 2007, whereas the employment in the other groups declines by -6 percent on average. This strongly suggests that the increase in Chinese export competition contributes significantly to the overall reduction in manufacturing employment in the EG countries.

Panel (b) of Figure 3 provides descriptive evidence that the production switches away from export-intensive industries that are affected by a strong Chinese export market competition into industries that are less prone to Chinese competition. After a modest increase between 1996 and 2000, the output value of the first group (high export intensity, strong Chinese export competition) has declined considerably. Overall, output dropped by -9 percent. On the other hand, the other groups of industries grew by 31 percent on average between 1996 and 2007.

In the next section, we analyze whether any effects of increased Chinese competition in the export markets are observable at the regional level, detached from industry classifications. 
Figure 3: Production and Employment by Degree of Export Competition and Export Intensity

(a)

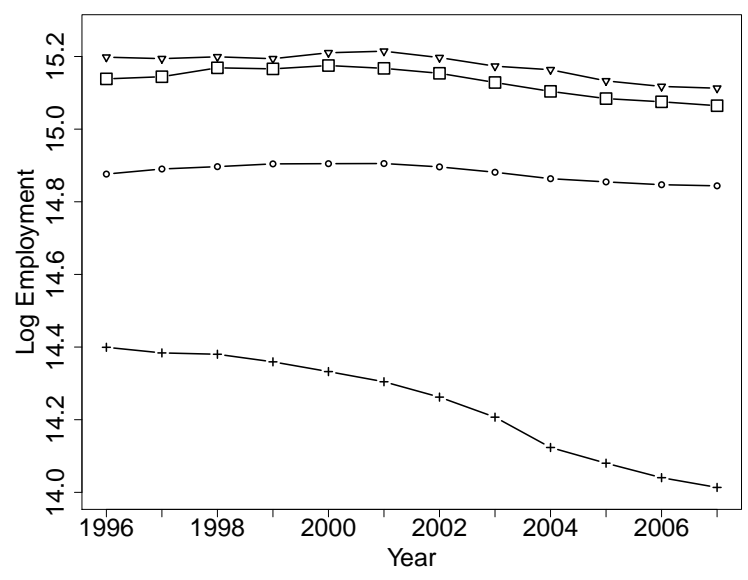

O Low Export Intensity, High Chinese Competition

$\square$ Low Export Intensity, Low Chinese Competition (b)

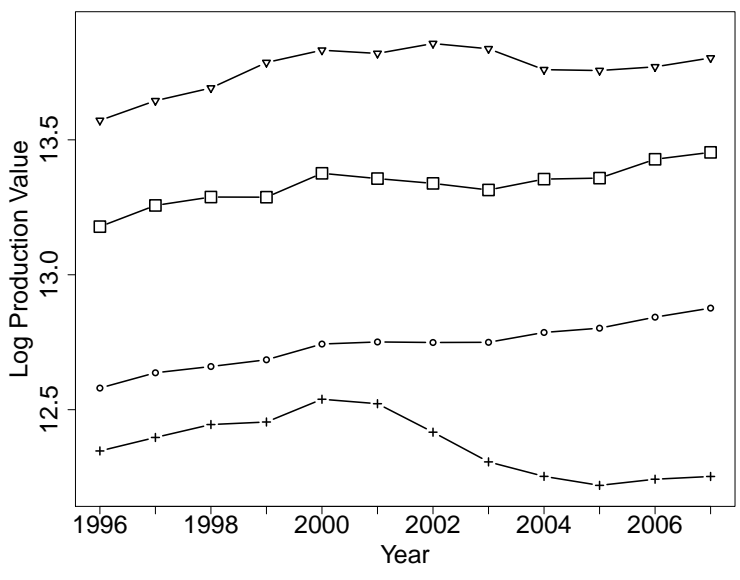

+ High Export Intensity, High Chinese Competition $\nabla$ High Export Intensity, Low Chinese Competition

Notes: The high (low) competition group is defined as follows: Industries for which the weighted export competition (WEC), as defined by Eq. [5, is above (below) average. The high (low) export intensity group is defined as follows: Industries for which the export intensity is above (below) average (OECD Structural Analysis Database). Panel (a): Time series plots of log employment for the different industry groups. Panel (b): Time series plots of log production value for the different industry groups.

\section{Chinese Competition and Changes at the Regional Level}

Up to now, our analysis of the effects resulting from increased Chinese export competition has been restricted to the manufacturing sector. In this section, we extend our analysis to the socio-economic dimension and investigate whether the changes within the manufacturing sector result in observable effects at a regional level, detached from any industrial classifications. We are especially interested in assessing whether the labor reallocation takes place exclusively within the manufacturing sector or whether other adjustment channels exist, such as inter-sectoral labor movements, transitions out of employment or geographical mobility. Given the strong effect of WEC on industry-level employment found in the previous section, we expect that the manufacturing sector is not able to absorb all the released labor, thereby leading to alternative adjustment channels.

Additionally, we also investigate whether increased Chinese competition in the export market affects the average wage rate in the manufacturing sector. In the previous section, we did not detect any price effects at the industry level. Therefore, we do not expect any association 
between wages and increased export competition. The existence of an effect on the servicesector wages will amongst others depend on the nature of the labor adjustment processes. Before turning to the presentation of the regression results, we first discuss the empirical strategy and present the data.

\subsection{Data Aggregation and EC Measure}

The indicators used as dependent variables are collected at regional level and do not allow for a differentiation among products or manufacturing industries. In order to use the trade data together with the variables reported at the regional level, we have to construct a regional-specific measure for the degree of Chinese competition in the export market. We use information regarding the regional distribution of industry-level employment to build the regional-specific EC measure. For each region we weight the industry-level trade data (see Section 5.3 with the region's share of nationwide employment within the given industry. Subsequently, the regionally weighted export competition (RWEC) measure is computed as the sum over the industry-level data that is weighted according to the regional employment structure. Formally, the RWEC measure is given by:

$$
R W E C_{i, z}=\sum_{g=1}^{G} W E C_{i, g} \frac{E m p_{i, z, g}}{E m p_{i, g}} \quad \forall z \in i, \quad \text { with } \begin{array}{r}
\text { country: } i=1, \ldots, I \\
\text { NUTS: } z=1, . ., Z \\
\text { industry: } g=1, \ldots, G .
\end{array}
$$

$W E C_{i, g}$ is the country-industry-specific weighted export competition measure from Eq.(5); $z=1, . ., Z$ are the different regions, $E m p_{i, g}$ is the total employment in the manufacturing industry $g$ in country $i$, and $E m p_{i, z, g} / E m p_{i, g}$ represents the regional-specific share of nationwide employment of industry $g .{ }^{25}$ Hence, we weight the country-industry-specific variable $W E C_{i, z}$ with the region $z$ 's share of industry $g$ 's total employment. By weighting all trade variables in such a manner, we transform trade-related data at the country level to the NUTS level. The regional-specific absolute trade volumes are computed according to Eq.(7) by simply using the industry-level trade volume variable instead of the WEC measure.

The variation in the trade flow data now stems from the assumption that changes in trade flows within a given industry are more relevant to NUTS regions in which a relatively high 
proportion of the industry workers are employed.

\subsubsection{Empirical Strategy}

As at the previous aggregation levels, we will use a fixed effects estimator in our regressions. The model is given by:

$$
y_{i, z, t}=\beta_{0}+\beta_{1} R W E C_{i, z, t-1}+\mu_{i, z}+\theta_{i, t}+\gamma_{t}+\boldsymbol{\beta}_{2}{ }^{\prime} \mathbf{X}_{i, z, t-1}+\epsilon_{i, z, t}
$$

where $y_{i, z, t}$ are the various regional-level dependent variables; $\theta_{i, t}$ are the country-specific time effects; and $\gamma_{t}$ are the time fixed effects. The country-regional-level fixed effects are represented by $\mu_{i, z}$, the error term by $\epsilon_{i, g, t}$. Again, our estimates only rely on variation over time. $R W E C_{i, z, t}$ is the regionally weighted EC; the set of control variables includes absolute import and export volumes as well as information on GDP levels for a given region. Because we only use intra-regional variation, the size of the region relative to the country does not matter.

\subsubsection{Threats to Identification}

We face the same potential problems with respect to the identification of the EC effect as in the previous sections. To avoid any spurious changes in the export competition measure which are unrelated to alterations in the regional exposure to Chinese competition in the export markets, we construct an instrument for $R W E C_{i, z}$ by substituting $W E C_{i, g}$ in Eq. (7) by our WPIV. To avoid any spurious correlation from changes in the weights, we additionally hold the regional-specific weights, i.e., the last term in Eq.(7), constant at their respective means.

Again our results are robust to common supply or demand shocks. ${ }^{26}$ Also, as shown in Table 5 column 1, the RWEC (and its instrument) are uncorrelated with the home country imports from China. This, in turn, implies that we can isolate the effect resulting from increased Chinese competition in the export markets. 


\subsection{Regional-Level Data}

The dependent variables differentiated with respect to geographical areas are again drawn from the Eurostat database. They are grouped according to the Nomenclature of Statistical Territorial Units (NUTS) and are completely detached from any industry classification. For our purposes, we use the NUTS 2 level. The data are available for all the EG countries except Denmark and Switzerland. These countries are subdivided into a total of 242 regions.

The dependent variables used for the regional level analysis are the number of persons employed (head count), the wage rate (thousand euros per hour), as well as the share of workers employed in the industry and service sector, respectively. The unemployment rate, the number of persons emigrating from a region (head count) and the share of the people emigrating below the age of 40 are also employed as LHS variables. In addition to the absolute trade volumes and the country-specific GDP levels, we also include the NUTS-level GDP (euro) and population (head count) into the set of control variables.

To the NUTS-level data, we then merge the regionally aggregated trade flow data. The variables included are the RWEC measure, as well as the regionally weighted total imports and exports.

Due to the loss of industry-specific variation, we unfortunately lose the tariffs applied to Chinese products in the partner countries as an additional instrument. The regionally weighted tariffs are no longer correlated with the EC measure and are therefore not suitable for use as an instrument.

The NUTS-level dataset contains 2,013 observations spanning the period 1995-2007. ${ }^{27}$ Through the aggregation process, the variation in the export competition measure (as well as the other trade flow variables) has changed compared to the product-level and the industrylevel dataset. Therefore, the point estimates presented in the subsequent section are not directly comparable to any previous results. Again, we try to simplify the interpretation by periodically reporting the RWEC effects when moving from its lowest to its highest quintile. Descriptive statistics of the variables used in the NUTS-level analysis are depicted in Table $? ?$ 
Table 5: Chinese Competition and Regional Labor Market Effects (1)

\begin{tabular}{lccc}
\hline $\begin{array}{c}\text { Dependent } \\
\text { Variable: }\end{array}$ & $\begin{array}{c}\text { Log imports } \\
\text { from China } \\
(1)\end{array}$ & $\begin{array}{c}\text { Log industry } \\
\text { employment } \\
(2)\end{array}$ & $\begin{array}{c}\text { Log service } \\
\text { employment } \\
(3)\end{array}$ \\
\hline $\begin{array}{c}\text { L. regionally } \\
\text { weighted PIV }\end{array}$ & 0.195 & & \\
$\begin{array}{c}\text { L. regionally weighted } \\
\text { export competition }\end{array}$ & $(0.145)$ & $-0.176^{* *}$ & $0.096^{* *}$ \\
$\quad$ First stage: & & $(0.054)$ & $(0.037)$ \\
L. regionally & & $0.500^{* *}$ & $0.500^{* *}$ \\
weighted PIV & 1996 & $(0.018)$ & $(0.018)$ \\
\hline Obs. Regionally weighted export comp. & 1996 & 1996 \\
RMSE & 0.271 & 0.047 & 0.024 \\
F-test excl. IV & 0.000 & 0.000 & 0.000 \\
\hline
\end{tabular}

Note: $* p<0.05, * * p<0.01$. FE estimator regressions in all columns with NUTS-specific effects; country-specific time trends; time dummies; and robust standard errors clustered at the NUTS level in parentheses. All regressions include NUTS-specific GDP and population in log; the weighted country-specific GDP per capita in log of constant international U.S. dollars; the regionally weighted sum of world imports and exports. F-test excl. IV is the pvalue of the instruments excluded in the first stage. RMSE is the root mean square error. The regionally weighted instrument (PIV) is our primary instrument as described in the main text aggregated over products and partners with a time-invariant weighting.

\subsection{SLS Results}

In this section, we present the regression results regarding the effects of increased Chinese export competition on the composition of the regional employment. The size and significance of the RWEC coefficients are robust with respect to the exclusion of the set of control variables (Tables ?? and ??). As shown in Table 5, column 1, the correlation between the regionally weighted PIV and the imports from China is not significant. These findings indicate that we are able to isolate the effects resulting from an increase in Chinese competition in the export markets. The F-test statistic of the excluded instrument in all subsequent first-stage regression setups documents that the models are again well identified.

Table 5, column 2, shows that the overall number of people employed in the manufacturing sector declines as the Chinese competition in the export markets increases. A one percentage point increment in RWEC is associated with a -0.17 percent reduction in manufacturing employment. This corresponds to a 2.4 percent decrease when moving from the lowest to the highest quintile in RWEC. Column 3 suggests that some of the labor released in the manufacturing sector reallocates to the service sector. The log number of persons employed in the service sector increases by 0.1 percent when the RWEC increases by one percentage 
Table 6: Chinese Competition and Regional Labor Market Effects (2)

\begin{tabular}{lccccc}
\hline $\begin{array}{l}\text { Dependent } \\
\text { Variable: }\end{array}$ & $\begin{array}{c}\text { Log wage rate } \\
\text { industry } \\
(1)\end{array}$ & $\begin{array}{c}\text { Log wage rate } \\
\text { service } \\
(2)\end{array}$ & $\begin{array}{c}\text { Unemployment } \\
\text { rate } \\
(3)\end{array}$ & $\begin{array}{c}\text { Log outwards } \\
\text { migration } \\
(4)\end{array}$ & $\begin{array}{c}\text { Migration } \\
\text { share }<40 \\
(5)\end{array}$ \\
\hline $\begin{array}{l}\text { L. regionally weighted } \\
\text { export competition }\end{array}$ & -0.038 & -0.046 & $2.812^{* *}$ & $0.297^{* *}$ & $0.055^{* *}$ \\
& $(0.065)$ & $(0.024)$ & $(1.044)$ & $(0.106)$ & $(0.019)$ \\
\multicolumn{7}{c}{ First stage: } & \multicolumn{7}{c}{ L. Regionally weighted export competition } \\
\cline { 2 - 6 } L. regionally & $0.596^{* *}$ & $0.596^{* *}$ & $0.501^{* *}$ & $0.525^{* *}$ & $0.525^{* *}$ \\
weighted PIV & $(0.024)$ & $(0.024)$ & $(0.018)$ & $(0.031)$ & $(0.031)$ \\
\hline Obs. & 1002 & 1002 & 1972 & 702 & 702 \\
RMSE & 0.030 & 0.016 & 1.197 & 0.059 & 0.010 \\
F-test excl. IV & 0.000 & 0.000 & 0.000 & 0.000 & 0.000
\end{tabular}

Note: ${ }^{*} p<0.05,{ }^{* *} p<0.01$. FE estimator regressions in all columns with NUTS-specific effects; country-specific time trends; time dummies; and robust standard errors clustered at the identifier level in parentheses. All regressions include NUTS-specific GDP (except in column (3)) and population in log; the weighted country-specific GDP per capita in log of constant international U.S. dollars; the regionally weighted sum of world imports and exports. Ftest excl. IV is the p-value of the instruments excluded in the first stage. RMSE is the root mean square error. The regionally weighted instrument (PIV) is our primary instrument as described in the main text aggregated over products and partners with a time-invariant weighting.

point.

The negative association between manufacturing employment and RWEC together with the positive relationship between RWEC and the number of people employed in the service sector implies that the manufacturing sector's relative importance declines in regions exposed to intensified Chinese export competition. Regions that exhibit an increased exposure to Chinese export competition therefore experience a shift in their employment structure. Industry declines and the service sector becomes (relatively) more important.

Turning our attention to the analysis of potential wage effects, the results in Table 6, columns 1-2 show that increased Chinese export competition is not associated with any significant effects, either in the manufacturing or in the service sector. These results are consistent with our findings at the industry level (Section 5). They can be explained by the rigid wages in Europe (see e.g. Babecký et al. (2010) or Druant et al. (2012)). Overall, the results reinforce our previous finding showing that increases in Chinese competition in the export markets are associated with quantitative labor adjustments, but not with any changes in wages.

As mentioned above, we observe a labor reallocation toward the service sector as a consequence of increased RWEC. Given that the inter-sectoral labor mobility is associated with considerable costs (e.g., Artuc and McLaren (2012) or Dix-Carneiro (2013)), we expect the 
labor adjustment to take place along additional channels. As column 3 of Table 6 shows, we find a considerable effect of RWEC on the unemployment rate. The coefficient of 2.8 implies that the (mean) unemployment rate increases by 2.9 percentage points when moving from the lowest to the highest quintile in RWEC. Additionally, we find that increased Chinese export competition is associated with an increase in the number of people moving away from a region. As depicted in column 4, a one percentage point increment in RWEC induces a 0.3 percent increase in outward migration. Since we have no access to suitable household-level data, we cannot assess whether the effect of outward migration is driven by the individuals who lose their manufacturing jobs or by other population groups; e.g., young people who decide to leave a region due to bleak labor-market perspectives induced by a decline in the industry sector. The presence of the last effect mentioned gains plausibility when looking at the results in column 5 . The share of emigrants who are less than 40 years old grows by 0.06 percent as the RWEC increases by one percentage point. The migration effects help to explain why regions with a dominant industrial sector that now face fierce competition in the export market wither. ${ }^{28}$

Overall, the results in this section have shown that the changes in the export markets due to increased Chinese competition are also detectable at the regional level, where quantitative labor adjustments are particularly prominent.

\section{Conclusion}

The emergence of China as the dominant producer of manufactured goods raises questions about the consequences for the industrialized world. Contrary to the existing literature, this study focuses on the analysis of the effects on developed European economies resulting from an increased competition in their export markets. For our empirical analysis, we use panel data covering several countries at multiple levels of aggregation. Applying an instrumental variable approach allows us to identify the effect of increased Chinese competition in the export markets. Additionally, it also enables us to isolate the export competition effect from the import competition effect. Various robustness checks demonstrate the validity of our results. 
Our findings document that the export volumes of manufactured products from European countries declines when Chinese competition in the export markets intensifies. This variation originating in the export market is strong enough to negatively affect the total output volume of the manufacturing industries within the EU countries. The associated adjustment processes are primarily of a quantitative nature. We observe a significant reduction in industry-specific employment as a result of increased exposure to Chinese competition in the export markets. Additionally, we establish a negative relationship between the degree of Chinese export competition and the average firm size. These findings corroborate the assertion that distortions in the export markets are reflected in adjustments within the affected industries in the home countries.

Using data aggregated at a regional level, we find that increased Chinese export competition induces a reduction in the total number of persons employed in the manufacturing sector. The results suggest three channels of labor adjustment: inter-sectoral and geographical mobility as well as a transition into unemployment. These effects provide an additional explanation for the withering of certain European regions with previously flourishing industrial sectors.

Overall, our paper demonstrates two things: First, it stresses the importance of the export sector in explaining changes within and across industries. Second, it shows that the developed countries are affected in various ways by the emergence of China as a dominant player in the global market for manufactured goods, and that they are consequently forced to adapt their production portfolios.

Some important aspects cannot be addressed in our study. For example, we cannot derive any implications about the effects of increased Chinese export competition on total welfare. Also, due to the lack of appropriate firm-level and household-level data, we cannot identify the adjustment processes that result from increased Chinese export competition at more disaggregated levels. These issues are left for future research. 


\section{References}

Affuso, Antonio, Roberta Capello, and Ugo Fratesi (2011) 'Globalization and competitive strategies in European vulnerable regions.' Regional Studies 45(5), 657-675

Álvarez, Roberto, and Luis Opazo (2011) 'Effects of Chinese imports on relative wages: Microevidence from chile.' Scandinavian Journal of Economics 113, 342-363

Álvarez, Roberto, and Sebastián Claro (2009) 'David versus Goliath: The impact of Chinese competition on developing countries.' World Development 37(3), 560-571

Andrews, Donald W.K., and James H. Stock (2005) 'Inference with weak instruments.' NBER Technical Working Papers 0313

Artuc, Erhan, and John McLaren (2012) 'Trade policy and wage inequality: A structural analysis with occupational and sectoral mobility.' Policy Research Working Paper Series 6194, The World Bank, September

Auer, Raphael A., Kathrin Degen, and Andreas M. Fischer (2013) 'Low-wage import competition, inflationary pressure, and industry dynamics in Europe.' European Economic Review 59(0), $141-166$

Autor, David H., and David Dorn (2013) 'The Growth of Low-Skill Service Jobs and the Polarization of the US Labor Market.' American Economic Review 103(5), 1553-97

Autor, David H., David Dorn, and Gordon H. Hanson (2013) 'The China Syndrome: Local Labor Market Effects of Import Competition in the United States.' American Economic Review 103(6), 2121-68

Babecký, Jan, Philip Du Caju, Theodora Kosma, Martina Lawless, Julián Messina, and Tairi Rõõm (2010) 'Downward nominal and real wage rigidity: Survey evidence from European firms.' Scandinavian Journal of Economics 112(4), 884-910

Basu, Sudip Ranjan (Forthcoming) 'Retooling trade policy in developing countries: Does technology intensity matter for GDP per capita?' In 'Policy Issues in International Trade and Commodities' (New York: United Nations) 
Bergoeing, Raphael, Timothy J. Kehoe, Vanessa Strauss-Kahn, and Kei-Mu Yi (2004) 'Why is manufacturing trade rising even as manufacturing output is falling?' American Economic Review 94(2), 134-138

Bernard, Andrew B., J. Bradford Jensen, and Peter K. Schott (2006) 'Survival of the best fit: Exposure to low-wage countries and the (uneven) growth of U.S. manufacturing plants.' Journal of International Economics 68(1), 219-237

Bernard, Andrew B., J. Bradford Jensen, Stephen J. Redding, and Peter K. Schott (2007) 'Firms in international trade.' Journal of Economic Perspectives 21(3), 105-130

Bernard, Andrew B., Jonathan Eaton, J. Bradford Jensen, and Samuel Kortum (2003) 'Plants and productivity in international trade.' American Economic Review 93(4), 12681290

Bloom, Nicholas, Mirko Draca, and John Van Reenen (2011) 'Trade-induced technical change? The impact of Chinese imports on innovation, IT and productivity.' Working Paper 16717, National Bureau of Economic Research

Broyer, Sylvain, and Felix Eschwege (2012) 'Migration in European industry during (19982009): A map-based illustration.' NATICIS Flash Economics 110, 1-18

Bucher, Hansjoerg, and Ralf Mai (2005) Depopulation and its consequences for the regions of Europe (Council of Europe)

Cadot, Olivier, Céline Carrère, and Vanessa Strauss-Kahn (2013) 'OECD imports: Diversification of suppliers and quality search.' Review of World Economics pp. 1-24

Dix-Carneiro, Rafael (2013) 'Trade liberalization and labor market dynamics.' Working Papers 1273, Duke University and Univeristy of Maryland

Druant, Martine, Silvia Fabiani, Gabor Kezdi, Ana Lamo, Fernando Martins, and Roberto Sabbatini (2012) 'Firms' price and wage adjustment in Europe: Survey evidence on nominal stickiness.' Labour Economics (0),- 
Ebenstein, Avraham, Ann Harrison, Margaret McMillan, and Shannon Phillips (2009) 'Estimating the impact of trade and offshoring on American workers using the current population surveys.' Working Paper 15107, National Bureau of Economic Research, June

Eichengreen, Barry, Yeongseop Rhee, and Hui Tong (2007) 'China and the exports of other Asian countries.' Review of World Economics 143(2), 201-226

Farole, Thomas, Andrés Rodríguez-Pose, and Michael Storper (2011) 'Cohesion policy in the European Union: Growth, geography, institutions.' Journal of Common Market Studies 49(5), 1089-1111

Fouarge, Didier, and Peter Ester (2007) 'Factors determining international and regional migration in Europe.' Technical Report, European Foundation for the Improvement of Living and Working Conditions

Hanson, Gordon H., and Raymond Robertson (2010) 'China and the manufacturing exports of other developing countries.' In 'China's Growing Role in World Trade' NBER Chapters (National Bureau of Economic Research, Inc) pp. 137-159

Husted, Steven, and Shuichiro Nishioka (2013) 'China's fare share? the growth of Chinese exports in world trade.' Review of World Economics (Weltwirtschaftliches Archiv) $149(3), 565-585$

Isgut, Alberto (2006) 'The effect of imports from China on Canada's labour markets: Your wages are not set in Beijing.' In 'Offshore Outsourcing: Capitalizing on Lessons Learned' University of Toronto pp. 12.1-12.24

Jenkins, Rhys (2020) 'China's global growth and Latin American exports.' Journal of Latin American Studies 42(4), 809-837

Knight, John, and Sai Ding (2012) China's Remarkable Economic Growth (Oxford: Oxford Scholarship)

López-Córdova, Ernesto, Alejandro Micco, Danielken Molina, Luis F. López-Calva, and Peter K. Schott (2008) 'How sensitive are Latin American exports to Chinese competition in the U.S. market?' Economía (2), pp. 117-153 
Melitz, Marc J. (2003) 'The impact of trade on intra-industry reallocations and aggregate industry productivity.' Econometrica 71(6), 1695-1725

Mion, Giordano, and Linke Zhu (2013) 'Import competition from and offshoring to China: A curse or blessing for firms?' Journal of International Economics 89(1), 202 - 215

Montenegro, Claudio E., Mariana Pereira, and Isidro Soloaga (2011) 'El efecto de China en el comercio internacional de América Latina.' Estudios de Economía 38(2), 341-368

Moreira, Mauricio Mesquita (2007) 'Fear of China: Is there a future for manufacturing in Latin America?' World Development 35(3), 355 - 376

Peltonen, Tuomas A., Martin Skala, Alvaro Santos Rivera, and Gabor Pula (2008) 'Imports and profitability in the euro area manufacturing sector-the role of emerging market economies.' Working Paper Series 918, European Central Bank, July

Pierce, Justin R., and Peter K. Schott (2012) 'The surprisingly swift decline of U.S. manufacturing employment.' NBER Working Papers 18655, National Bureau of Economic Research, Inc, December

Puga, Diego (2002) 'European regional policies in light of recent location theories.' Journal of Economic Geography 2(4), 373-406

Riad, Nagwa, Luca Errico, Christian Henn, Christian Saborowski, Mika Saito, and Jarkko Turunen (2012) Changing Patterns of Global Trade (International Monetary Fund)

Sargent, John, and Linda Matthews (2009) 'China versus Mexico in the global EPZ industry: Maquiladoras, FDI quality, and plant mortality.' World Development 37(6), 1069-1082

Schott, Peter K. (2008) 'The relative sophistication of Chinese exports.' Economic Policy $23,5-49$

The Conference Board (2013) 'Total Economy Database'

Xing, Yuqing (2011) 'China's exports in information communication technology and its impact on Asian countries.' Economic Change and Restructuring 44(1), 135-147 


\section{Notes}

${ }^{1}$ Source: UN Comtrade Database.

${ }^{2}$ See e.g., Riad et al. (2012), Table 5.

${ }^{3}$ Source: OECD Structural Analysis Database.

${ }^{4}$ For comparison, the degree of export intensity for the U.S. manufacturing sector lies at 14 percent.

${ }^{5} \mathrm{~A}$ product class is defined as facing intense Chinese competition if more than 20 percent of the world exports originate in China.

${ }^{6}$ For example, exporting firms have been shown to be more productive, to employ more workers and to pay higher wages than non-exporters (e.g., Bernard et al. (2007)).

${ }^{7}$ However, the reader should bear in mind that the impact on wages can only be measured for the workers remaining in the manufacturing sector. The effects for workers leaving the sector can be quite different, as documented by Ebenstein et al. (2009).

${ }^{8}$ See Fouarge and Ester (2007).

${ }^{9}$ For example, using the absolute volume of Chinese imports in the trade partner country as a proxy for the forgone exports is not possible since we cannot directly observe the elasticity of substitution between imports from different countries.

${ }^{10}$ The Appendix is available at www.cje.economics.ca.

${ }^{11}$ UN Comtrade Database

${ }^{12}$ To substantiate our assumption further, we perform a simple falsification exercise, where we regress lagged exports of country $i$ to partner $j$ on our instrumental variable (regression not shown here). If negative European supply shocks are the cause of the increase of the EC measure, one would expect the decrease in exports to precede the increase in the competition index. The results, however, show no economically or statistically significant relationship.

${ }^{13}$ We do not expect any problems regarding weak instruments, since all the values of the first-stage Fstatistics are large (Andrews and Stock, 2005).

${ }^{14} 100\left(\exp ^{-0.3 / 100}-1\right)=-0.3 \%$.

${ }^{15}$ The countries belonging to this group are: Australia, Japan, Rep. of Korea, Canada, Chile, New Zealand, Israel and the United States.

${ }^{16}$ According to the IMF, following countries are classified as emerging economies: Argentina, Brazil, Bulgaria, Colombia, Estonia, Hungary, India, Indonesia, Lithuania, Malaysia, Mexico, Pakistan, Peru, Philippines, Poland, Romania, Russia, South Africa, Thailand, Turkey, Ukraine and Venezuela.

${ }^{17}$ Formally: $E X_{k}^{T}=\sum_{j=1}^{J} E X_{j, k}$

${ }^{18}$ Written formally: $E X_{g}^{T}=\sum_{k=1}^{K} \mathbb{I}\{k \in g\}\left(\sum_{j=1}^{J} E X_{j, k}\right)=\sum_{k=1}^{K} \mathbb{I}\{k \in g\} E X_{k}^{T}$ 
${ }^{19}$ In probabilistic terms, this measure corresponds to the expectation across partners and products with the weights as distributions.

${ }^{20}$ In the previous section, we have assumed that export competition directly (contemporaneously) affects the dependent variables. Using lagged values of the explanatory variables does not qualitatively change the results of the regression model Eq. 2 .

${ }^{21}$ Formally, the instrument is defined as: $\sum_{k=1}^{K} \mathbb{I}\{k \in g\} \overline{\left(\frac{E X_{k}^{T}}{E X_{g}^{T}}\right)} \sum_{j=1}^{J} \frac{I m_{j, k}^{C}}{\sum_{c \neq i} I m_{j, c, k}} \overline{\left(\frac{E X_{j, k}}{\sum_{j=1}^{J} E X_{j, k}}\right)}$, where the bar indicates the average.

${ }^{22}$ The NACE classification encompasses not only manufacturing, but also other sectors. Again, we restrict the analysis to the manufacturing sector, implying the inclusion of the NACE codes 17-37.

${ }^{23}$ The industry-level tariff rates are computed analogously to the weighting procedure depicted in Eq. (5). The product-level EC measure is simply replaced by the product-level tariff rates.

${ }^{24}$ Overall industry employment decreased by -10 percent from 1996 to 2007.

${ }^{25}$ Note that by using this weight, the EC measure no longer necessarily lies between zero and one.

${ }^{26}$ Regression including the our additional instruments are available on request.

${ }^{27}$ The number of observations available varies depending on the LHS variable.

${ }^{28}$ See for example Affuso et al. (2011) and Bucher and Mai (2005). 